\title{
Transparentność przegród w aspekcie relacji wnętrza i zewnętrza budynku
}

\section{Transparency of partitions in relation to the interior and exterior of the building}

\begin{abstract}
Streszczenie
Relacja wnętrza budynku i jego przestrzeni zewnętrznej jest obecnie podstawowym komponentem w projektowaniu architektonicznym jako zintegrowanym całościowo zamysłem przestrzennym. Otwarcie budynku na kontekst najbliższego otoczenia służy budowie ekspresji wizualnej, atrakcyjnej estetyki budynku i jego plastycznego wyrazu ale również kreacji wewnętrznych wrażeń przestrzennych związanych ze światłem. Uzyskanie wszelkich efektów kompozycyjno-plastycznych i krajobrazowych jest możliwe dzięki zastosowaniu transparentności przegród, świadomego użycia światła w budynku. Innym aspektem takich rozwiązań jest możliwość budowy przestrzeni uniwersalnej, gdzie następuje zatarcie granic pomiędzy wnętrzem a zewnętrzem projektowanego obiektu. Nie bez znaczenia jest tu użycie odpowiednich materiałów, które podkreślają jedność połączenia, a przegroda jest jedynie formalnym zamknięciem przestrzeni. Jest to szczególnie ważne w projektowaniu relacji krajobrazowych z wnętrzem, które otrzymuje poza wyreżyserowanym widokiem naturalne oświetlenie. Możliwość wykorzystania transparentnych ścian w architekturze zawdzięczamy zastosowaniu najnowszych rozwiązań technologicznych, które pozwalają wprowadzać bez ograniczeń duże powierzchnie przeszklonych tafli. Transparentność może wówczas działać w obie strony przegrody, na zewnątrz i do wnętrza obiektu.
\end{abstract}

\begin{abstract}
The relationship between the interior of the building and its outer space is now the basic component in architectural design as a holistic integrated spatial solution. The opening of the building to the context of the immediate surroundings serves to build a visual expression, attractive aesthetics of the building and its artistic expression, but also the creation of interior spatial impressions connected with the light. All compositional and plastic effects and landscape effects are achieved through the use of transparent partitions, the conscious use of light in the building. Another aspect of such solutions is the possibility of building a universal space, where the boundaries between the interior and exterior of the designed object are blurred. Not without significance here is the use of appropriate materials that emphasise the unity of the connection and the partition is only the formal closure of the space. This is particularly important in the design of relationships landscape - interior, which outside the planned view is given a natural lighting. The ability to use transparent walls in architecture is due to the use of state-of-the-art technology that allows large areas of glazed glass to be introduced without limitation. Transparency can then act on both sides of the barrier, outside and inside the object.
\end{abstract}

Słowa kluczowe: transparentność, wnętrze, zewnętrze, światto

Keywords: transparency, interior, exterior, light

Wykorzystywanie transparentności jest częścią zabiegów przestrzennych i wizualno-plastycznych stosowanych do kształtowania relacji pomiędzy wnętrzem a zewnętrzem obiektów architektonicznych. Transparentność działa w obie strony skracając dystans pomiędzy tym co znajduje się przed i za przegrodą, pomiędzy tym co może być strefą prywatną i publiczną, pomiędzy tym co daleko i blisko, podchodząc do przestrzeni wnętrza i otoczenia budynku jako zintegrowanego całościowo problemu architektonicznego. Przezierność przegród stosowana często we współczesnych budynkach jest całkowitym przeciwieństwem architektury dośrodkowej,
The use of transparency is part of spatial and visualplastic procedures used to shape the relationship between the interior and exterior of architectural objects. Transparency works both ways shortening the distance between what is in front of and behind the partition, between what may be an area of private and public, between what is far and near, approaching the interior space of the building and the environment as an integrated whole architectural problem. The translucence of partitions often used in contemporary buildings is the complete opposite of the centripetal architecture, enclosed 
zamkniętej na swoje otoczenie, której narracja przestrzenna zycji skończonej, ograniczonej dla odbiorcy płaszczyznam widocznych ścian. Współczesne muzea, galerie handlowe, obiekty wystawiennicze oraz użyteczności publicznej positkują się często doświetleniem górnym, które na tyle wystarczające i intensywne zapewnia wymagany komfort świetlny w niektórych partiach obiektu, wzmocnione jest jednak dodatkowo świattem sztucznym. Transparentność niezależnie dat tego w jakim zakresie sto od tego w jakin zakresie sos zabiegle wa ja rów plan achych achickn i jej nablizszego sąsiedztwa. Otwacie czow

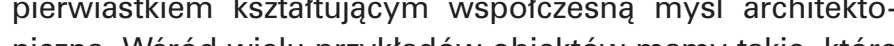

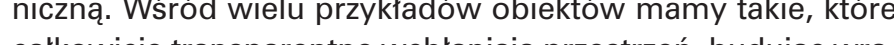
calko wicie transparen pa zenia wizualne i wielokronosc pespekty wiznych planów stając się prawie niematerialne. Tego typu rozwiązania posiadają wiele walorow, ale nie są praktyczne w użykowaniu. Dlatego kreatorzy wspólczesnej architekury stosują bardziej akceptowalne rozwiązania, jakimi są doświetlenia określonych części budynku przez transparentne przegrody, budując $z$ kolei $w$ drugą stronę wyreżyserowane perspektywy, widok punktowe i panoramiczne. W taki sposób powstaje obustronna relacja pomiędzy wnętrzem a jego przestrzenią zewnętrzną, a wciąganie zewnętrznego otoczenia do środka obiektu pozwala zatrzeć granicę pomiędzy tym co prawdziwe i materialne, a tym co jest jedynie wrazeniem wizualnym, estetycznym i celowym zabiegiem przestrzennym.

\section{Swiatło we wnętrzu obiektu}

Podstawowym założeniem transparentności przegród jest doświetlenie i nasłonecznienie przestrzeni architektonicznej, ale również nadanie lekkości i otwartości czy wrẹcz przeświettenie wnętrza budynku, ukazujacc nie tylko zawarte w nim elementy konstrukcyine, strukture i wyposażeni, ale równiez toczące się $w$ przestren wow ictrace żcie. Budynek jest struktura dynamiki dyna wi i bez podzica w ízich

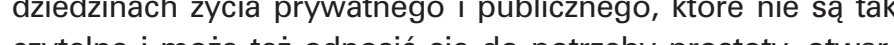

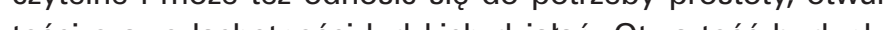

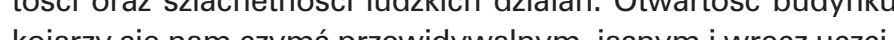
kojarzy sie nam czymś przewidy dalnym, jasnym i węcz uczciwym tak jak tlumaczy to materiał do tego celu uzyty. Szkło jest tworzywem uniwersalnymi trwalym, a przede wszystkim daje możliwośc uzyskania wielu efektów plastycznych', wizualnych i niezwykle przestrzennych kreacji w architekturze. Dzięki zdobyczom współczesnej technologii stosowanie bez ograniczeń szklanych przegród i płaszczyzn nie byłoby możliwe, a jedyna uciążliwością mogą być obecnie względy ekonomiczne inwestora lub inwencja twórcza projektanta.

Swiatło jest najważniejszym czynnikiem w kreacji architektury od momentu koncepcji po realizacje. Swiatto to życie, kolor, faktura, forma, kształt i ciepło. Swiatło ma także wiele istotnych sfer działania w przestrzeni architektonicznej od wizualnych po użytkowe. Jest przyczynkiem (...) zmiennych in its surroundings, whose spatial narrative takes exposition restricted to the viewer by visible walls. Contemporary museums, shopping galleries, exhibits and public utility objects often feature high-end illumination that sufficiently and intensively provide the required light comfort in some parts of the faciity, but is also enhanced with artificial light. Transparency regardless of the extent to which it is use intended to increase the ortistic valtectural treatment and its immedie vicinity Opening to both the environment and natural light is an en temporary architectural thinking. Among the many examples of objects that completely transparently absorb space, build visual impressions, and enlarge prospective plans by becoming almost intangible. These types of solutions have many advantages bu are not practical in use. Therefore, modern architectural creators use more acceptable solutions to illuminate specific parts of a building through transparent partitions, while building directed, point and panoramic views. In this way, a mutual relationship between the interior and its outer space is created and drawing the outer environment into the centre of the object allows the boundary between the real and the material, and what is merely a visual, aesthe and intentional spatial impression to be blurred.

\section{The light inside the obje}

The basic assumption of the transparency of the the architectural space, but also the lightness and openness of the building, or even the illumination of the interior of the building showing not only the structural elements, structure itself and equipmen contained in it, but also the inner life. The building is an open structure in which the rhythm of day and night, work and rest, dynamics and immobility pulsate live. This kind of transparency may be the basis for human desire to be transparent in many areas of private and public life that are not as readable and may also address the need for simplicity, openness and the nobility of human activities. The openness of the building we associate something predictable, clear and honest as the material used for this purpose. Glass is a durable universal material and, above all, gives the opportunity to create many artistic, visual and spatial creative effects in architecture. Without the achievements of the modern possible, and the only limitations can be economic situation of the investor or designer's creativity Light is the most important factor in the creation of architecture from conception to realisation. Light is life, colour, texture, form, shape and heat. It also has many important spheres of activity in architectural space from visual to utility. It is the contribution of "(...) time variables, fleeting light effects, architectural influences (emphasizing and enhancing objects, or on the contrary - views deformatio illusory disappearance of the image), defining ar- w czasie, ulotnych wrazen swietlnych, oddziaływania na bryły lub przeciwnie, zakłócanie widoku poprzez deformację, zanikanie iluzoryczne obrazu), definiowania przestrzen architektonicznejlokreślanie, podkreślanie granic lub ich przekraczanie, podziat, unifikacie, hierarchizaciel),wprowadzania znaczenia (kontekstu)poprzez działanie kontemplacyjne metaforyczne, symboliczne, duchowe $(. . .)^{2}$. Światto posiad równiez funkcie użytkowe jak choćby energia cioposiac nie powszechnie wykorzystywan w budownictwie, obecze walory zdrowotne zwiazane z funkcjonowaniem naszego ze wasy z w jego wymiarze fizycznym (pobudzanie skóry do wytwa wa je wy

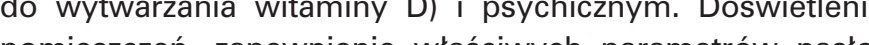

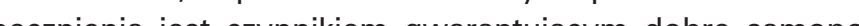
czocie we whe czy i zdrom gwa psychiczu uzykow samopoczrcie we wétru izdrowie psychiczne uzykow sow takiej przestrzeni. Swla to stowez psychiczne uzyclowików takiej znacznie na altruistyczne zachowania ludzi, wzmacnia chęc do pracy i wszelkie fizyczne aktywności, ale również podnos poczucie satysfakcji z życia czyli usposabia pozytywnie i czy ni ludzi bardziej szczęśliwymi³. Komfort "świetlny" można uzyskać nie tylko dzięki nasłonecznieniu wnętrza, ale w większym zakresie dzięki odpowiedniej wielkość przeszkleń, gdyż używanie dużych powierzchni okiennych ma bardzo isto we znaczenie terapeutyczne. Jest to szczególnie widoczne w szpitalach i ośrodkach zdrowotnych, kiedy okna wychodz na piękny krajobraz i przyjemny widok ${ }^{4}$. Bezpośredni kontak $z$ naturą może działac regeneracyjnie na człowieka zapewniając mu szybszy powrót do zdrowia, ale i równowagę emocjonalną $w$ codziennym życiu.

\section{Kontakt $\mathbf{z}$ otoczeniem - postrzeganie krajobrazu}

Potrzeba kontaktu człowieka z atrakcyjnym widokiem czy krajobrazem wynika z uciążliwości współczesnego życia związanych ze stresujaca egzystencja oraz praca w mieście a realizacja tej potrzeby niesie za soba wiele korzyści taczność z notura pozwala na zachowanie zdrowia psychicznego i fizycznego człowieka. Wprowadzanie do wnetrza bunego nym, zaar zowanie widoku krajobrazowego czy zwyklego

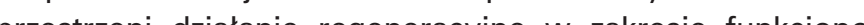
prania psychik. Nastepuace w ten spośb (. .) reakcje regwania psych iki Nastepujce wey ten spos (...) reakcje regeneracyjne obejmuja redukcje stresu psychicznego, redukcje agresji oraz regeneracje energili i zdrowia (... $)^{5}$. Regenerujące i kojące wasciwosci sceneril naturalnych dotyczą łagodzenia napięcia związanego ze stresem bieżącym, a nawet moga doprowadzic do uodpornienia, łagodzącego konsekwencje przyszłych stresow. Innym aspektem wglądu w scenerię naturalną z użytkowanego wnętrza jest zwolnienie ukierunkowanej uwagi związanej z wysilkiem umysłowym (egzamin, praca) i aktywizacji uwagi tzw. mimowolnej, która nie wymag wiele wysilku. Dalej sceneria naturalna moze stać się źródłem fascynacji i przyciągać uwage swymi zjawiskami przyrodniczymi. Po naturalnej fascynacji może nastapić czas refleks ji I odprężania co zazwyczaj doprowadza do ukierunkowani uwagi na istotne cele życiowe chitectural space (defining, highlighting or crossing, unification, hierarchization), the introduction of meaning (context) through contemplative, metaphorical, symbolic, spiritual action'. Light also has utility functions, such as heat energy currently used in construction, but also the health benefits to our body's physical function (skin stimulation for vitamin $D$ production) and mental health. Illumination of the rooms, proper sun exposure is a factor to f such space. Sunlight lifts mood ald of users the altruistic behiviour of people, strengthens the desire to work and all physical activity, but also increases the sense of satisfaction in life, which makes people happier ${ }^{2}$ "Light" comfort can be achieved not only by the sunlight in the interior but to a greater extent thanks to the appropriate size of glazing because of the use of large windows therapeutically significant. This is particularly noticeable in hospitals and health centres where the windows overlook the beautiful landscape and pleasant view3. Direct contact with nature can help regenerbut also an emotional balance in his daily life.

Contact with the environment - the perception of he landscape

The human need to interact with an attractive view or landscape is due to the nuisance of modern life and fulfilling this need has mand work in the cily. tion with nature allows you to maintain mental and physical health. Entering the interior of the building visual contact with the environment, the arrangement of the landscape view or the usual concentration of green vegetation provides users with this space of regenerative action in the psyche. Following in this way "(...) regenerative reactions include reduction of mental stress, reduction of aggressio and energy regeneration and health $(. . .)^{\prime \prime 4}$. Regenerating and soothing properties of natural scenery relieve tension associated with current stress and may even lead to "mmunisation, mitigating the consequences of future stress" of insight into the natural environment of the interior is to free the focused attention associated with mental effort (exam, work) and to activate the atention of the so-called involuntary, which does not require much effort. Then natural scenery can become a source or fascination and attract attenforion, the may be time for reflection and (1) which usually leads to a focus on important life goals ${ }^{6}$.

In relation to the interior of the building and its surroundings, one can find a reference to Kazimierz Wejchert's vision theory. The constraints that the interior creates for the observer of a framed outer view are only a fragment of the environment, the kind of interior, and the reception of such space is subjective. Mainly due to different lighting condi- 
W relacjach wnętra budynku i jego otoczenia można znaleźć odniesienie do teori widzenia Kazimierza Wejcherta. Ograniczenia, jakie tworzy wnettrze dla obserwatora kadrowanego widoku zewnetrznego jest jedynie wycinkiem środowiska, rodzajem wnętrza, a odbiór takiej przestrzeni ma charakter subiektywny. Głównie ze względu na odmienne warunki oświetlenia, różne nastroje ${ }^{8}$ i klimat, ale także odmienne formy przestrzeni zewnetrznej i wewnetrznej. Na styku dwóch środowisk przestrzennych o odmiennych parametrach zawartych w formie i treści znajduja sie miejsca punktów granicznych Wonne i trasci zaju

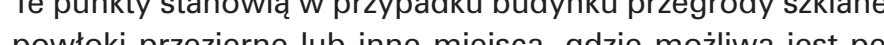
nowraki przezlere netracja olocze. Przebywajac w stodowisku zamkniętym np. whęrza budy Pu, oczekujeny, ze w miejscu granicznym wzrok nasz podązy w przestrzen o warta, ciekawa, jakiej nie znat lub nie spodziewal się uprzednio. Intrygująca niepew-

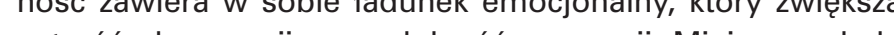
ostrosc obserwacji oraz zdolnośc percepcji. Miejsce wglądu zawiera olbrzymie możliwosci kompozycyjne ${ }^{10} \mathrm{i}$ może dostar-

O wrodzonych skłonnościach człowieka do sposobów zachowań w sytuacji postrzegania krajobrazu oraz preferencji niektórych miejsc w tymże krajobrazie mówi Janusz Skalski w swej książce", powołując się na teorie "widok - schron"12. Zgodnie z nią człowiek lubi znajdowac się w miejscu, w którym doskonale widzi, ale sam nie lubi być widziany. Dlatego najodpowiedniejsze do obserwacji jest umowne wnętrze odczuwalne jako schron. Za takie można uznać pomieszczenia w budynkach, które wyposażone $w$ okna dają możliwość wglądu w daleki krajobraz ${ }^{13}$. Odbiór krajobrazu w przestrzeni wzrokowej jest podstawowym źródłem informacii, a na te podstawie uruchamia się proces percepcji. Będąc w bezruchu, obserwatorem statycznym na granicy wnetrza i zewnetrza obiektu odbieramy widoczny przez nas krajobraz jako stały panoramiczny obraz ${ }^{14}$. Jest to istotne w kreacii wyreżserowanych widoków przestrzeni, plastycznych, trafiajezy do naszej percepcii wzrokowej i pobudzajacych wraże estetyczne. W ten sposób uczestniczymy w zdarzenizhia estyczen dąc zaraze Wé w w a przeziernoscc
strzeganie.

Transparentność - drugi wymiar rzeczywistości

Jest wiele obiektów architektonicznych transparentnych, o cechach przenikalności wizualnej i czytelnej relacji pomiędzy wnętrzem i zewnętrzem. Jednym z ważniejszych przykładów to "Glass House" Philipa Johnsona, gdzie transparentność dematerializuje się na tle otaczające przyrody, a wnętrze domu jest właściwie na zewnątrz obiektu. Przepływająca przez szklany prostopadłościenny kształt budynku przestrzen nie znajduje barier poza czerwonym ceglanym walcem wy rastającym z podłogi i wydostającym się ponad dach ${ }^{15}$. Otaczający krajobraz wkrada się do wnętrza poprzez przeszklenia pozwalając wyobrazni budować wrazenia jedności z malowniczym otoczeniem. Jednak budynek ten choć prowadzi grę w przestrzenną nieskończoność, która jest przerwana jedynie odbiciem przyrodniczego otoczenia w szklanych taflach ent forms of outer and inner space. At the junction eters contained in the form and content are border points'. These points in the case of a building are glass walls, translucent coatings or other areas where penetration of the surrounding is possible. By staying in a closed environment such as the interior of a building, we expect that in a borderless location our eyes will go into an open space, fore. Intriguing insecurity embraces an emotional load that enhances the focus of observation and the ability to perceive. The place of insight contain enormous compositional possibilities ${ }^{8}$ and can deOn the innate tendencies of man to behat the situation of the perception of the landscap and the preferences of some places in the same landscape, says Janusz Skalski in his book', referring to the theory of "view - shelter" ${ }^{10}$. According to this theory, a man likes to be in a place where he sees perfectly, but he does not like to be seen. Therefore, the most suitable for observation is the contractual interior perceived as a shelter. As such can be considered rooms in the buildings, where windows give an insight into the wide landscape. Reception of the landscape in the visual space is sis trimary source of information, and on this basis triggers the perception process. As a static obthe object, we see the landscape as a continuous panoramic image ${ }^{12}$. It is important in the creation directed views of space that reach our visual perception and stimulate aesthetic impression. In this way we participate in events, being their observer and at the same time inside the object. The transparency of the shell facilitates play with space and its perception.

Transparency - the second dimension of reality There are many transparent architectural objects with visual permeability and a clear relationship between the interior and exterior. One of the most important examples is Philip Johnson's "Glas House", where transparency is dematerialized against the surrounding nature, and the interior of the home is actually outside the facility. The space flowing through the glass rectangular shape of the building does not find any barriers except for the red brick roll rising from the floor and escapcreeps into the interior through glazing allowing imagination to build a sense of unity with the picturesque surroundings. However, this building, athough playing the game into spatial infinity, which is interrupted only by the reflection of the natura environment in the glass wall, has a private area unavailable to the eyes function as a fireplace and bathroom.

The authors of another building with the appearance of the glass aquarium - Carlo Santambrogio and Ennio Arosio - went even further in their reflec-
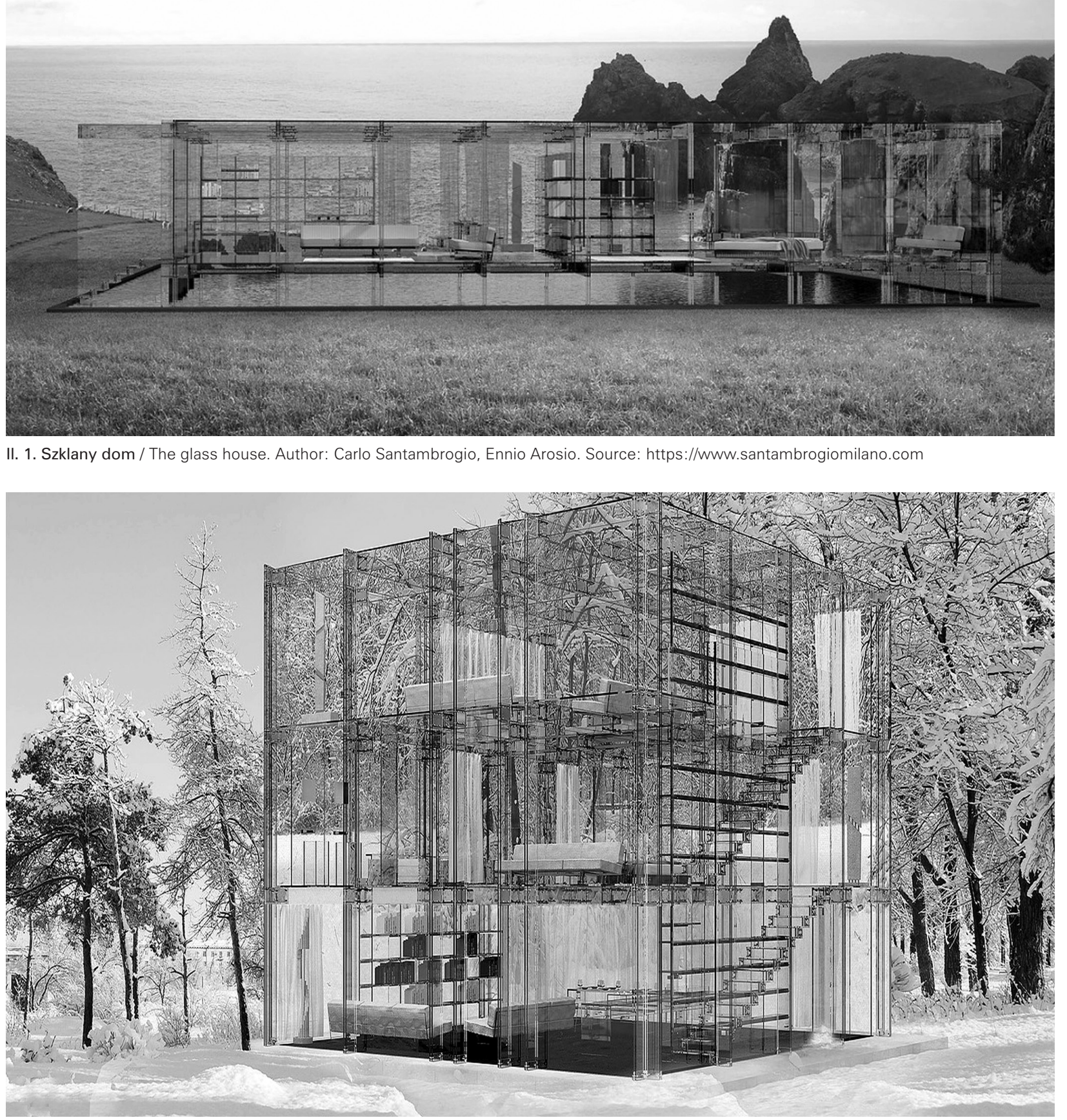

II. 2. Szklany dom / The glass house. Author: Carlo Santambrogio, Ennio Arosio. Source: https://www.santambrogiomilano.com II. 3. Crescent house. Author: Make Architect. Source: http://www.archello.com/en/project/crescent-house

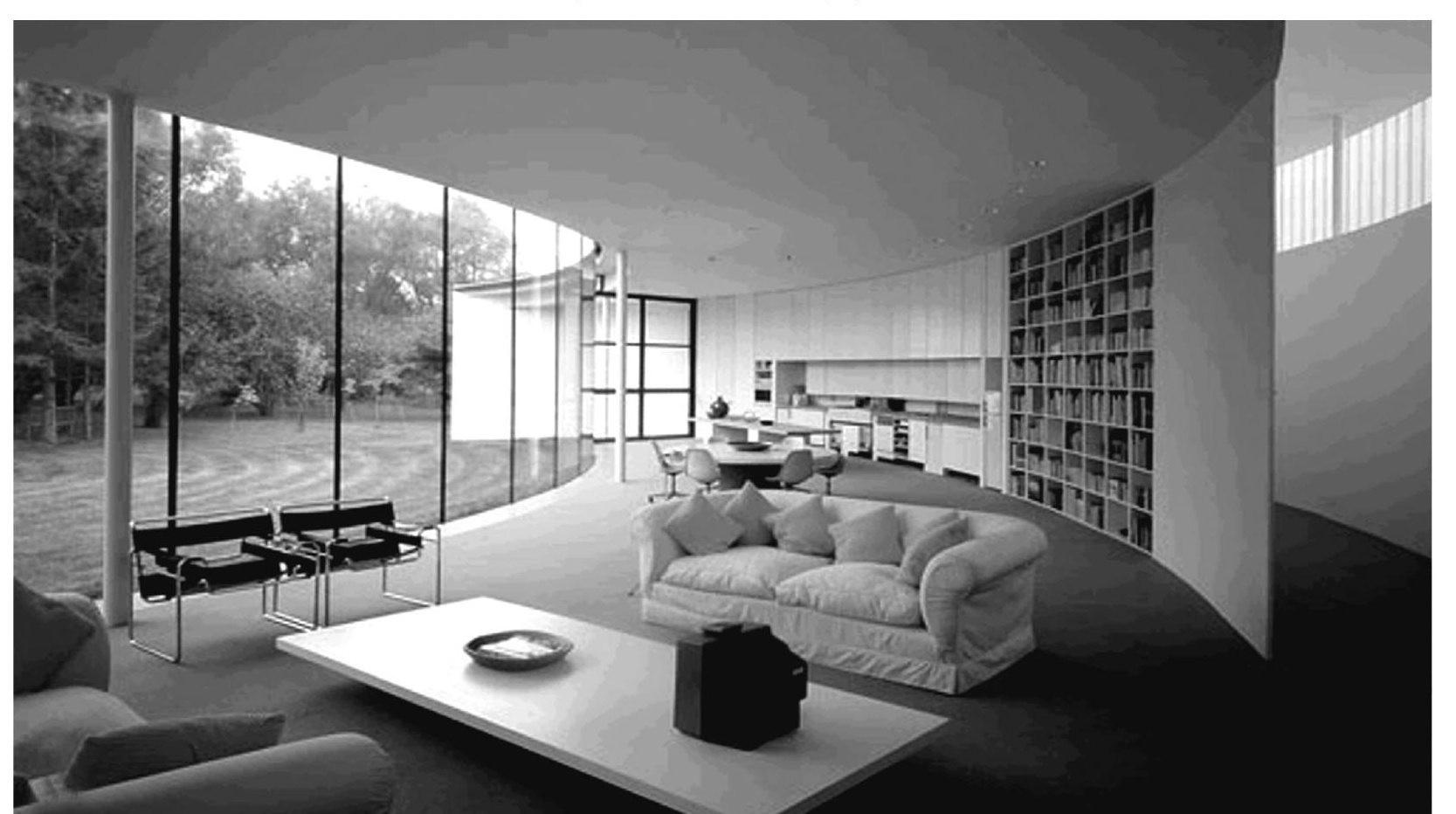


ścian, posiada strefę prywatną, niedostępną dla oczu kryjącą funkcję kominka i łazienki.

Jeszcze dalej w swych rozważaniach o transparentności poszli autorzy innego budynku o wygladzie szklanego akwarium Carlo Santambrogio i Ennio Arosio. Zaprojektowany jako trzykondygnacyjny dom $\mathrm{w}$ lesie, czy jego wersja $\mathrm{w}$ formie pawilonu usytuowanego $w$ otoczeniu fiordów, obiekt ten jest całkowicie wykonany ze szkła o lekko niebieskawym zabarwieniu. To po pierwsze popis rozwiazzń architeky zabarprzy użyciu szkła nośnego i gos w dyskusii na temicznych przy użyil szḱa nośnego i glos $w$ dyskusjí na temat jego

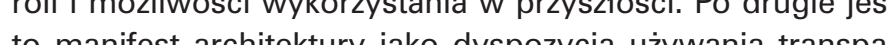
to manfest ach wy rentnosciw życi, kreacil przostzon prybawionej intymności i prywas oni schronu da najlogodnieszej obserwacji i kontemplacji srodowiska. W domu calkowicie przenikahym strefa wizualna jego whętrza i zewnętrza jest polączona i tworzy jedność. Przenikalnoscią przystaje i upodabnia się do natury $i$ otoczenia, czegos nieuchwytnego i ciągle podlegającego kolorystycznym i świethym zmianom w zależności od pory dnia czy sezonu. Dom zamieszkuje krajobraz poddając się jego fenomenowi ${ }^{16}$. Przegrody szklane nie blokują wzroku dając możliwośc wglądu W nieskończoność krajobrazu i niezwykłość zjawisk przyrodniczych jednak granica pomiędzy wnętrzem i zewnętrzem istnieje na styku dwóch środowisk, naturalnego i sztucznego. Osiągnięto wrażenie lewitacji sprzętów domowych o stylistyce opartej na rozwiązaniach ze szkła, gdzie jedynie podłoga drewniana odcina się płaszczyzna poziomą od podłoża. Architektura ulotna, nierzeczywista utworzona przez zagęszczenie kolorytu błękitnej struktury przegród poziomych i pionowych oraz zespolonych z nią elementów wyposażenia. Najważniejszym komponentem architektury staje się naturalne światło. Przenikanie światta przez dwa światy naturalny, zewnętrzny i sztuczny, stworzony przez kreacje architektoniczna, przestrzeń oraz materiat, tworzy niematerialny wydźwiek transparentnej struktury.

\section{Wgląd do wnętrza}

Przenikalność wizualna $w$ architekturze działa niezaprzeczalnie w obie strony, choć jej znaczenie nie jest równoważne. Otwartość budynku na zewnątrz prowokuje do tego, aby zaglądnąc do wnętrza. Jednak jest to tylko gra pozoru. Obserwacja zewnetrzna jest możliwa, ale przestrzeń jest ograniczona przegrodą, odcięta powłoką szklaną, a widz nie jest do niej bezpośrednio dopuszczony. Obserwator zewnętrzny jest tylko biernym uczestnikiem tego, co odbywa się we wnętrzu. Dostępnośc wzrokowa przestrzeni zaciera granicę pomiędzy strefą publiczną a prywatną co jest domeną współczesnych obiektów użyteczności publicznej. Odrębne terytoria o różniącym się charakterze oferują całkiem przeciwstawne środowiska i odmienne doświadczenia dla odbiorcy. Uzasadnienie użycia transparentności można też odnaleźć w ksztattowaniu elewacji budynku. Przestrzeń otwarta dla odbiorcy to przestrzeń symboliczna, a jej idea związana jest z funkcją i przeznaczeniem obiektu. Miejsca o większym znaczeniu i wybitne lokalizacji są akcentowane wielkością otwartych przeszklen pozwalając na odczytywanie scenariusza zdarzeń nakreślone- tions on transparency. Designed as a three-storey house in the woods, or its version in the form of a pavilion surrounded by fjords, this property is entirely made of light blue-tinted glass. Primarily, this is a demonstration of architectural solutions using a carrier glass and a voice in the discussion about it role and potential future use. Secondly, it is a manifesto of architecture as a disposition of the use of transparency in life, the creation of a space deprived Iy mentioned shelter theory for the most ybservation and contemplation of the environment In a completely pervasive home, the visual zone of its interior and exterior is connected and creates unity. Its permeability is consistent and conforms to nature and environment, something elusive and yet still a subject to colour and light changes depending on the time of day or season. The house inhabits the landscape by surrendering to its phenomenon ${ }^{14}$ Glass partitions do not block the view, giving the opportunity to view the infinity of the landscape and the extraordinary nature of natural phenomena. However, the boundary between the interior and the outside exists at the contact of two environments, natural and artificial. The levitation of home-style appliances has been achieved thanks to glass solutions, where only the wooden floor is cut off from the ground by a horizontal plane. The unilateral architecture was created by densifying the colour of titions and the ass he horizontal and vertical parportant component of architecture light. The penetration of light through the natura outer and artificial worlds, created by the architectural creation gible effect of a transparent structure.

\section{Insight into the interior}

Visual permeability in architecture works undeniably in both directions, although its meaning is no equivalent. The openness of the building provokes you to look inside. However, this is just a gam of appearances. Exterior viewing is possible, but space is bounded by a partition, cut off by a glas cover, and the viewer is not directly "let in". A external observer is only a passive participant of what is going on inside. The visual accessibility of the space blurs the boundary between the public and private areas, which is the domain of moder public facilties. Distinct territories of differing naperiences for the recipient. The justification for the use of transperency can also be found in shaping the facade of a building. For the receiver, the ope space is a symbolic space and its idea is roped to the function and purpose of the object. Places of greater importance and outstanding location ar accentuated by the size of open glazing allowing to read the script of events outlined by the designe of buildings ${ }^{15}$. However, the transparency of the façade is a controlled openness, providing more than the safety of use, the exposure of directed go przez projektanta budowli". Jednak transparentnosc elewazpia stanowi otwartośc kontrolowaną zapewniając nie tylko bezpieczeństwo użytkowania, ekspozycję wyreżyserowanych widoków zwiazzanych z użytkowaniem budynku i obrazów Crescent House to budynek zaprojektowany przez Make Architect $i$ jest to przykład nowoczesnego podejścia do tradycyjnej przestrzeni mieszkalnej zamknietej w niekonwencjonalnej formie. Emenement polega tu na znakomity potaczeniu ksztatu półksięzyca który jak sie zydaje idym nie przystaje do przestrzeni życiowej, ze światem zewrea

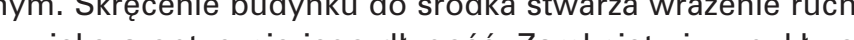
zwiç strony drogl obiekt, otwiera ramiona do whętrza ogrod

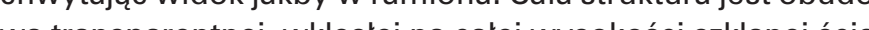
wą transparentnej, whęsej na calej wysokosci szklanej ściany's, która clągnie się wzdnz przestrzeni wspolnej, w które wydzielono kuchnię, salon i jadalnię. Przez ten zabieg architekt zapewnit dużą ilość światła $w$ strefie dziennej, ale rów niez wzmocnil symbolke najbardiej prestizowej przestrzen tego założenia. W ciągu dnia przepiękne widoki na przyrod i zieloną dolinę wzbogacają transparentne wnętrze, ale widzialnosć z zewnątrz jest zaburzona przez barierę, jaką stanowi odbicie światta i krajobrazu w szklanej powierzchni. Elminuje to widzialność poszczególnych planów i dostępnośc wizualną wnętrza nadając architektonicznemu zamysłow plastyczną tajemniczość.

\section{Podsumowanie}

Transparentność w architekturze sprzyja kreacji przepływu przestrzeni pomiedzy wnetrzem a zewnetrzem obiektu architektonicznego. Jest to podstawowy element współczesnej architektury, promującej przestrzeń otwarta, kontaktową i odśrodkową. Użycie światła w kreacjach architektonicznych poza efektami użytkowymi i estetycznymi ma olbrzymie pozypywne znaczenia dla zdrowia psychicznego cztowieka, emocjonalnej rómnowagi oraz jego fizycznej aktywności. Budowa cozwiazán widokowych z wnetrza przestrzeni aschi. Budowa nej jest nie tylko poszukiwaniem rozwiazań kompozycyjnych fascynacji plastycznych, ale przede wszystkim dążeniem do osiagnięcia swobody i nieskrepowanej wolności wizualne o jest bezwzgledna potrzebą współczesnego życia. Iluzja niematerialności może być też świadomym działaniem przezierności architektury jako efekt nakładających się planów i odbic światta, a granica między wnêtrzem i zewnętrzem stanowic jedynie bariere umowna. Wszystko po to, aby w świecie zztuczności i materialnych kreacji zbliżyć się do wyobcowanego naturalnego środowiska.

PRZYPISY

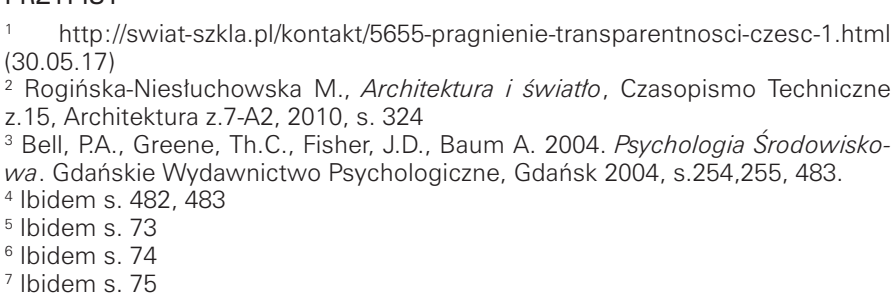

views related to the use of the building and plastic images based on natural light and its reflection. Crescent House is a building designed by Make Architect and an example of a modern approach to traditional residential space enclosed in an unconventional form. The unprecedented combination consists of an excellent combination of crescen shape, which seems to fit perfectly in the living space with the outside world. Twisting the building and opticlly increases its length. A cloved and convex object opens its arms to the inside of the garden with a view as grasping arms. The entire structure is a transparent, concave casing over the top to the bottom glass wall16 that spreads along the shared space that separates the kitchen, living room and dining area. Through this operation, the architect provided a large amount of light in the day zone but also reinforced the symbolism of the most prestigious space of this premise. During the day, beautiful views of nature and the green valley enrich the transparent interior, but visibility from the outside is disturbed by the barrier that reflects light and landscape in the glass surface. This elim nates the visibility of individual spaces and the vsual accessibility of the interior giving the archite

\section{Summary}

Tansparency in architecture fosters the flow of space between the in aclior and exterior of an architectur chitecture, promoting open, contact and centrifugspace. The use of light in architectural creations beyond utility and aesthetic effects has enormously positive implications for mental health, emotiona balance, and physical activity. The construction of visual solutions from the interior of the architectura space is not only a search for compositional solutions and artistic fascination but above all the purs of sovereignty and unassisted visual freedom, which is the absolute need of modern life. The illusion of intangibility can also be a deliberate act of the transparency of architecture as the effect of overlapping plans and reflections, and the boundary between the interior and the outside is only a contractual barrier Everything serves the purpose in the world of artificito get closer to the alienated natural environment.

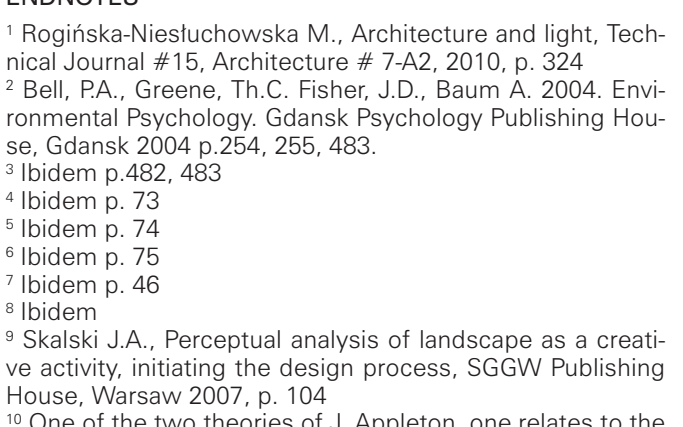


8 Wejchert. K. Elementy kompozycji urbanistycznej, Wydawnictwo Arkady, 1984, s. 25

${ }^{9}$ Ibidem s. 46

${ }^{10}$ Ibidem

${ }^{11}$ Skalski J.A., Analiza percepcyjna krajobrazu jako działalność twórcza, inicjująca proces projektowania, Wydawnictwo SGGW, Warszawa 2007, s. 104

12 Jedna z dwóch teorii J. Appletona, jedna dotyczy środowiska, druga, tzw. widok - schron

${ }^{13}$ lbidem s. 105

14 Ibidem s. 121

15 http://www.archdaily.com/60259/ad-classics-the-glass-house-philip-johnson (dostęp 31.05.17)

${ }^{16}$ https://www.santambrogiomilano.com/the-glass-house (dostęp 31.05.17)

17 Palej A., Homiński B., Strefa przejściowa, Czasopismo Techniczne 3-A/2010, Zeszyt 6, rok 107, s.101.

18 http://www.archello.com/en/project/crescent-house (31.05.2017)

\section{LITERATURA}

[1] Bell, P.A., Greene, Th.C., Fisher, J.D., Baum A. 2004. Psychologia środowiskowa. Gdańskie Wydawnictwo Psychologiczne, Gdańsk 2004.

[2] Palej A., Homiński B., Strefa przejściowa, Czasopismo Techniczne 3-A/2010, Zeszyt 6, rok 107 (on-line 28.05.2017).

[3] Rogińska-Niesłuchowska M., Architektura i światło, Czasopismo Techniczne z.15, Architektura z.7-A2, 2010, (on-line 30.05.17).

[4] Skalski J.A., Analiza percepcyjna krajobrazu jako działalność twórcza, inicjujaca proces projektowania, Wydawnictwo SGGW, Warszawa 2007.

[5] Twarowski M., Słońce w architekturze, Wydawnictwo Arkady, Warszawa 1996.

[6] Wejchert. K. Elementy kompozycji urbanistycznej, Wydawnictwo Arkady, 1984.

\section{INNE ŹRÓDŁA INFORMACJI:}

http://www.sztuka-architektury.pl/article/4481/transparentnosc-w-architekturze (30.05.2017)

http://www.archdaily.com/60259/ad-classics-the-glass-house-philip-johnson(31.05.2017)

https://www.santambrogiomilano.com/the-glass-house(31.05.2017)

http://www.archello.com/en/project/crescent-house(31.05.2017) environment, the other, the so-called shelter view

11 Ibidem p. 105

12 Ibidem p. 121

13 http://www.archdaily.com/60259/ad-classics-the-glass-house-philip-johnson [Accessed 31.05.17]

$1^{4}$ https://www.santambrogiomilano.com/the-glass-house [Accessed 31.05.17]

${ }_{15}$ Palej A., Homiński B., Transition zone, Technical Journal 3-A/2010, Notebook 6, year 107, p.101.

16 http://www.archello.com/en/project/crescent-house (31.05.2017)

\section{BIBLIOGRAPHY}

[1] Bell, P.A., Greene, Th.C. Fisher, J.D., Baum A. 2004. Environmental Psychology. Gdansk Psychology Publishing House, Gdansk 2004

[2] Palej A., Hominski B., Transition zone, Technical Journal 3-A/2010, Notebook 6, year 107, p.101. (On-line 28.05.2017).

[3] Roginska-Niesłuchowska M., Architecture and Light, Technical Journal \#15, Architecture \#7-A2, 2010, (on-line 30.05.17).

[4] Skalski J.A., Perceptual analysis of landscape as a creative activity, initiating the design process, SGGW Publishing House, Warsaw 2007.

[5] Twarowski M., Sun in architecture, Arkady Publishing House, Warsaw 1996.

[6] Wejchert. K. Elements of Urban Composition, Arkady Publishing House, 1984.

\section{OTHER SOURCES:}

http://www.sztuka-architektury.pl/article/4481/transparentnosc-w-architekturze [Accessed 30.05.2017]

http://www.archdaily.com/60259/ad-classics-the-glass-house-philip-johnson [Accessed 31.05.2017]

https://wwW.santambrogiomilano.com/the-glass-house[Accessed 31.05.2017]

http://www.archello.com/en/project/crescent-house [Accessed 31.05.2017] 